\title{
The Remaking of Institutions for Local Climate Governance? Towards Understanding Climate Governance in a Multi-Level UK Local Government Area: A Micro-Local Case Study
}

\author{
Erica Russell * and Ian Christie
}

check for updates

Citation: Russell, E.; Christie, I. The Remaking of Institutions for Local Climate Governance? Towards Understanding Climate Governance in a Multi-Level UK Local

Government Area: A Micro-Local Case Study. Sustainability 2021, 13, 13817. https://doi.org/10.3390/ su132413817

Academic Editors: David Tyfield, Rebecca Willis and Andy Yuille

Received: 15 October 2021

Accepted: 8 December 2021

Published: 14 December 2021

Publisher's Note: MDPI stays neutral with regard to jurisdictional claims in published maps and institutional affiliations.

Copyright: (c) 2021 by the authors. Licensee MDPI, Basel, Switzerland. This article is an open access article distributed under the terms and conditions of the Creative Commons Attribution (CC BY) license (https:/ / creativecommons.org/licenses/by/ $4.0 /)$.
Centre for Environment and Sustainability (CES), Arthur C Clarke Building, Stag Hill Campus, University of Surrey, Guildford GU2 7XH, UK; i.christie@surrey.ac.uk

* Correspondence: erica.russell@surrey.ac.uk

Abstract: The crisis of climate disruption and shortcomings in top-down approaches has focused attention on the effectiveness of governance to achieve climate goals. New sub-national governance models such as business alliances, city networks and NGO coalitions have emerged; such institutional 're-making' is often motivated by frustration at national inaction, and by a belief thatlocal actors offer an effective 'bottom-up' approach. Literature on the emergence of climate-led multi-level and polycentric governance focuses primarily on cities; the role of urban-rural counties and of the microlevel of local government, and the challenges and opportunities before them, is less well studied. This paper draws on work in progress in a study exploring progress, challenges and failings in UK climate governance across multiple levels of county-based government: Surrey, an area of towns, peri-urban districts and countryside, is offered as a case study, with a focus on micro-level action in small towns and parishes. We find that despite a lack of national government orchestration or sub-regional frameworks, climate action is occurring voluntarily at all levels of governance. However, the nature of action is variable and irregular and there is little evidence as yet to demonstrate effectiveness. A fragmented form of multi-level governance is observed, with limited upward flows of ideas and no indication of national interest in micro-local climate lessons and experience. We identify the importance of 'wilful actors' and the need for greater coordination, information- and knowledge-sharing networks to achieve effective institutional 'remaking' for climate action.

Keywords: climate change; multi-level governance; institutional remaking

\section{Introduction}

As the science of climate change has advanced, and concerns over climate disruption have mounted, in recent decades, interest has grown in the implications of climate crisis for governance, the complex interplay of governmental and non-governmental institutions, processes and cross-sectoral and multi-level relationships of policy actors in problem definition and problem solving, agenda setting, orchestration of strategies and policies, and the management of public goods (see, for example, [1-7]). The focus of research and policy development has been mainly at the global and national scales, with the evolution of trans-national institutions such as the UN Framework Convention on Climate Change, the International Panel on Climate Change, and policy making on climate within international networks such as the EU. There has been considerable attention in the academic and policy literatures on global and national governance of climate action in the context of ecological disruption, the negotiation of targets for greenhouse gas emissions reduction, and the failures of national governments to implement effective measures to achieve goals set in international agreements (see, for example, [4,5,8-14]).

There has also been significant work in academic research and policy development on the local governance of climate action-focusing predominantly on the role of urban municipalities and leading cities (see, for example, [15-23]). This reflects the political and 
economic weight of major cities, and also the role taken by many of them in promoting more radical policies on the climate crisis than have been advanced by their national governments. We have seen the emergence of numerous city-led initiatives for climate action, such as the C40 Cities network at the global scale, and of initiatives led by urban mayors in the USA to accelerate climate action in the absence of leadership at the federal level following the Kyoto Protocol of 1997 [19,21,22].

The significance of local governance of climate policy as a source of exemplary and pioneering action across sectors [24] has been underlined by the well-documented and serious failure so far of national governments to implement international climate agreements, incentivise decarbonisation and set their economies on course for achieving net zero greenhouse gas emissions, consistent with the goals of the Paris Accord $[5,25,26]$. Together, the literatures on emergent climate governance approaches at global and city scales provide a significant body of knowledge and theory on the benefits and failings of top-down and bottom-up policy development, contributing to understanding of multi-level governance for climate action and more generally for sustainable development $[2,4,6,7,15,27,28]$.

However, so far, the literature on governance and climate challenges has not focused to the same degree on local climate governance in non-metropolitan areas, where local administrations and their network relationships with other policy actors cover towns, peri-urban and suburban localities and rural districts, and include relationships with 'micro-local' institutions such as parish and small town councils. Such places generate a physical, political, social and economic 'mixed ecology' very different from that governed by major city authorities. Given the political and social significance of such territories, and the distinctive policy challenges they pose (for example, the greater degree of car dependence in affluent non-metropolitan areas than in cities and greater opportunities for re-forestation), it is important to explore the opportunities, problems and emerging patterns in governance of climate action at this scale.

We suggest that more work is needed on this level of governance to enhance our understanding of the development of institutions and processes for coping with climate change, and to enrich the well-established literatures on multi-level and polycentric forms of governance in general. More important, better understanding of local governance of climate crisis could help to improve its processes and outcomes, and thereby contribute to climate change mitigation and adaptation.

In this paper, we introduce some findings from an on-going research project in the UK, that aims to improve understanding of emergent climate governance institutions and processes at the sub-regional local scale in a non-metropolitan area, the county of Surrey in South-East England. We outline some initial results from a multi-level case study involving three layers of local government and related governance processes and networks.

While the research focus is specifically on this part of the UK, we hope that the approach taken and findings so far will resonate with researchers and policy makers in other contexts, given the wide range of states with similar challenges concerning the relationship between centralized national power and local/regional actors in the context of designing and implementing effective climate mitigation and adaptation strategies. The structure of this paper is as follows. We first set out the broad policy and research context for this study; then, in Section 2, we present our case study method at the micro-level of local governance in our selected area; in Section 3, we outline the results at the time of writing (early autumn 2021); finally, we discuss the findings to date.

\subsection{The Policy Context}

The policy context for this study is the existing framework of local government and governance in England, and the political debates about its future and the pressures on the system as it stands. The local government system has been subject to substantial reforms over the past half-century and a stable settlement remains elusive. There is a complex multi-level array of institutions in the formal local government system, complemented by a complex set of networks of cross-sectoral partnerships and other governance bodies. 
There are unitary authorities, single-tier local government institutions overseeing services for an area: some are metropolitan areas, but some are rural-suburban territories. There are also multi-tier areas where a county council must work with borough (largely urban) and district (largely rural) smaller authorities, which in turn have below them parish and town councils, the smallest units of local government. Such an area is the county of Surrey, the focus of our project as explained below.

Alongside, and entangled with, these local government bodies are networks of local governance, in which public, private and voluntary sector bodies work in advisory, research, policy development, delivery and advocacy coalitions. Such bodies include the Local Economic Partnerships (LEPs) established by national government as forums and sub-regional agencies for local skills, infrastructure and investment; the new and rapidly evolving network of local Climate Commissions, established by local government bodies and partners independently of central government; and many long-standing multisector partnerships on aspects of policy such as nature conservation, waste, and local energy systems.

What these diverse local government and governance institutions have in common is the impact of the recent history of central government policy making in relation to local governance. The trend has been towards centralisation of power in English government, despite the numerous phases of local government reform over recent decades $[29,30]$; and local government has been subject to a major reduction in power and resources in the years since the global financial crash of 2008 [31]. The imposition of 'austerity', in particular since 2010 under the then Conservative-Liberal Democrat coalition government of the UK, has greatly constrained local government and governance bodies, reduced their funding and weakened their capacity [32]. The past decade has also seen the abolition of regional assemblies and development agencies in England, thus removing the regional tier of government and governance, and leaving regional and sub-regional coordination in the hands of complex overlapping networks of local councils, new combined authorities (run by elected mayors, mainly in major metropolitan areas), and partnership organisations such as the LEPs [33,34].

A major development at the local level has been the reduction in core grant financial settlement from central government and the subsequent loss of staff, skills and discretionary activities from local government services [31]. At the same time, the demands on the core statutory services provided by local councils-such as adult and social care-have grown, with the ageing of populations and the impact on physical and mental health of economic insecurities and, since 2020, of COVID-19 [35,36]. Additional finance for local government has typically been provided by central government via once-off targeted grants and via funds available on a time-limited competitive bidding process. Local government in England remains very restricted in its capacities to raise revenues locally and to engage in strategic planning and investment in major infrastructures [35,37].

These developments have greatly constrained the development of climate policy and its implementation at the local level: climate action has been pursued, but has been hampered by lack of political priority, funds, staff and skills [38]. However, in many local authorities and among their local governance partners, there have been numerous initiatives for climate action in spite of the unfavourable financial and operational context $[24,37,38]$. In 2019, the worldwide upsurge in climate campaigning (Extinction Rebellion, School Strikes for Climate, and Climate Emergency Declarations) sparked a wave of interest and activity in UK local government and among local governance actors. Climate Emergency declarations were made at a large scale [38].

The rise in salience and urgency of climate policy since 2018 has focused attention at the local level on the gap between aspirations and local potential for effective climate action on the one hand, and the institutional weakness of local government on the other. Calls for much greater attention to local potential and capabilities, for a clear framework for climate action, and for climate-focused institutional reform have come from local government representative bodies such as the County Councils Network [39] and UK100 [40]; from 
national policy advisory bodies [41-44]; and from think-tanks (see, for example, [37,38,45]. These demands have in common a call for a coherent debate and framework concerning the role of local government and governance partners in the design and implementation of the UK Government's ambitious strategic goals for decarbonisation [46]; and a call for recognition of the essential role to be played by local actors in achieving net zero climate mitigation goals and implementing adequate adaptation measures in the face of climate disruption. This extract from the National Audit Office's [35] report on Local Government and net zero in England is representative of this body of critique, analysis and recommendations concerning policy gaps and lack of orchestration across levels of government in pursuit of effective climate governance and implementation:

"While the exact scale and nature of local authorities' roles and responsibilities in reaching the UK's national net zero target are to be decided, it is already clear that they have an important part to play, as a result of the sector's powers and responsibilities for waste, local transport and social housing, and through their influence in local communities. Government departments have supported local authority work related to net zero through targeted support and funding. However, there are serious weaknesses in central government's approach to working with local authorities on decarbonisation, stemming from a lack of clarity over local authorities' overall roles, piecemeal funding, and diffuse accountabilities. This hampers local authorities' ability to plan effectively for the long-term, build skills and capacity, and prioritise effort." [35] (p. 12)

In recent years, in tandem with this wave of critical analysis of UK climate policy, we have seen the emergence and spread of a bottom-up movement for debate and institutional development concerning local governance of climate policy, in the absence of the called-for framework for national-local orchestration of net zero strategy and adaptation plans. The Place-Based Climate Action Network (PCAN, https:/ / pcancities.org.uk, accessed 12 October 2021) has developed in recent years in the UK as a new force in climate governance, entirely initiated by local government and governance actors (notably universities) and based on the establishment of cross-sectoral local Climate Commissions as orchestrators and coordinators of climate strategies and projects at the local level [24,39]. The PCAN network began with a core of major cities (Leeds, Edinburgh, and Belfast) and has since expanded to include smaller metropolitan areas (Kirklees and Croydon); a major region (Yorkshire and Humberside in the north of England); and several counties spanning towns, suburbs and large rural areas (Surrey, Essex, and Cambridgeshire).

As we note below in Section 1.2, the emergence of the PCAN network and the widespread demands for a coherent framework to enable local climate action within a national strategy have highlighted a persistent theme in local climate governance over the past three decades: the way in which local actors have frequently developed policy in the absence of a clear framework from national government, or in the face of national leaders' opposition to climate action (as in the case of the USA under President Trump [47]). Where a framework for national-local shared planning, implementation and orchestration is missing, then piecemeal or coordinated bottom-up governance arrangements have emerged. Drawing on Patterson [48], we term this approach 'compensatory' and improvisational re-making of institutions for climate action. The development of the still-patchy network of Climate Commissions at the local level in the UK is a case in point.

The changing policy context in the UK raises important questions about the design and implementation of effective institutions and processes for local climate governance. What should these be like? What seems to work well in new emergent systems for local governance of climate action? We suggest that the changes exemplified by the PCAN network and related initiatives [24] are signs that the UK is experiencing the beginning of what Patterson [48] terms institutional remaking for climate action:

'the activities by which agents intentionally develop political institutions in anticipation of, or in response to, institutional weaknesses and failures' [48] (p. 25). 
We reflect further on this point in Section 1.2 below, and then consider in detail emerging results from our current research into recent and prospective developments in local climate governance in the English county of Surrey, a local government area covering towns, extensive suburban zones, and rural districts. In particular, we describe work in progress in mapping and understanding such institutional remaking at the smallest scale of local government and governance in England, the town and parish level.

\subsection{Understanding Local Climate Governance}

As noted above, there is by now a large, rich and complex literature on climate governance from global to local scales. Valuable overviews of the field can be found in $[2,5,6,9,13,21]$. It is beyond our scope to reflect on more than a few elements of the literature that shed light on our research goal, that of exploring the emergence of microlocal institutions for climate action in a case study area in southern England. Below, we highlight briefly the following themes from the literature and use them to set the scene for our discussion of case study findings:

(A) The debate over multi-level and polycentric approaches and models for climate governance;

(B) The failings and challenges to effectiveness in climate governance, and the consequent need for remaking of institutions [48];

(C) The relative lack of attention paid to micro-level governance.

There is a substantial literature on the concepts and realisation in practice of multilevel governance (MLG) and polycentric governance (PG) in relation to climate action in particular and sustainability more generally (see, for example, $[6,12,13,27])$. Both concepts seek to represent the role and interaction of multiple levels and centres of policy making, implementation, coordination and agenda setting, recognising that systemic problems of the kind posed by climate change cannot be handled at one master level of government or via one mode of governance (i.e., the cooperation of governmental bodies with stakeholder organisations across sectors in problem definition, management and implementation of policies). They also have affinities with the ideal type concept of subsidiarity, in which functions are devolved to the most local level consistent with effective policy and decision making for the issue at stake. MLG and PG approaches recognise that climate change is a systemic challenge that has impacts at every scale from global to micro-local, and that must be governed accordingly in a flexible and multi-scalar way. They point to the need for new or adapted forms of 'orchestration' between institutions at the international, national and lower scales, to coordinate climate policy and achieve the goals established in global agreements on climate [1,49]. Research and policy questions then arise concerning what arrangements are being tried; what works and what does not; and what normative analysis can be made of what we ought to do for climate governance at multiple scales across sectors and levels of government.

Heinen et al. [6] offer a comprehensive review of the debates and distinctions offered concerning MLG and PG. We concur with their analysis, which suggests that the concepts have emerged from distinctive intellectual traditions (American and European approaches to governance) and that they have been used more or less interchangeably by many researchers: "As climate governance researchers draw on the intellectual foundations of both perspectives, it has been increasingly difficult to clearly distinguish between both concepts despite their different origins." [6] (p. 10). Heinen et al.'s [6] analysis of the literature generates a framework in which commonalities between MLG and PG become apparent and more significant than the distinctions offered by analysts. In effect, they propose a merger of MLG and PG perspectives. The common features in these perspectives are identified as follows by Heinen et al. [6] (p. 2 and p. 10):

- A recognition of climate change as an interdependent policy problem;

- The role of multiple decision makers, based on diverse relevant statutory responsibilities;

- $\quad$ The presence of multiple decision-making centres that must interact in diverse ways; 
- The presence of 'rules in use' that shape and guide decision making-whether legally required rules or self-regulated processes; and

- The 'degree of dependencies' - the extent to which there is 'a formalized degree of dependency' among decision-making centres, 'which may be formally independent, formally interdependent, or choose to interrelate their decisions.'

Drawing on Heinen et al. [6], and given the entanglement of MLG and PG perspectives, we propose to use 'multi-level governance' as a term that spans both these concepts as they have developed in the literature. MLG refers not only to the formal statutory constitutional levels of government (central and local in the case of England, for example) but also to the 'horizontal' governance relations of collaboration with other bodies (such as multi-sector strategic partnerships) and to the 'vertical' relationships between tiers of government. Accordingly, we will present our case study of Surrey as one MLG in the face of climate challenges.

We turn now to the second major theme we wish to highlight from the literature: the constraints and problems affecting emergent institutions for climate governance. One important aspect of the debates over MLG, PG and climate governance is that, so far, climate policy in toto has been a failure, given the rise in global emissions despite multiple pledges and policy measures, and that the emergence of local governance innovations for climate action has been to a large degree based on frustration at the absence of effective policy and multi-level cooperation. Harris [5] identifies multiple sources of what he terms 'pathologies' in climate governance at the international and national scales. Stoddard et al. [26] review and attempt to explain the collective international and national failures to 'bend the curve' of greenhouse gas emissions and put the world on course for meeting the Paris Accord goals and keeping global average temperature rise to 1.5 degrees C. Parry et al. [25] analyse the extraordinary scale of subsidies from governments for fossil fuel interests worldwide. The power of established fossil fuel industries and their supporters and clients in governments and other bodies, and country-specific barriers to action rooted in national politics and economic path dependency, generate multiple interacting 'pathologies' [5] that have meant that, so far, international and national climate governance and political programmes for decarbonisation have been seriously compromised and have failed to stop the rise in emissions, let alone to reduce them at the global scale.

It is in this context that many high-profile local climate governance initiatives have emerged, whether at thr horizontal international level (as with for example the C40 network of cities, the R20 network of regional governments, and the ICLEI network of local authorities for sustainability) or at the local level within countries. The development of such collaborations and orchestrating institutions has taken place not only out of a positive impetus for making a contribution at the local and regional levels to climate action, but out of frustration at the failures of national governments and international actors to live up to their agreed goals for serious decarbonisation policies. See, for example, this statement from ICLEI [50] in the wake of the Rio + 20 conference on sustainable development in 2012:

"We now see that all the good will, energy, brain capacity and money that went into the Rio +20 process have resulted in dozens of pages of paper, which contain hardly any commitment by governments. Instead, national governments reaffirm what they had already resolved long ago, list non-binding intentions, and acknowledge the activities by other actors such as local governments. It remains unclear who should be in charge and accountable for taking decisions on the transformative actions needed, and for rapid implementation. Do cities have to step in where governments are failing to take effective action? Cities are cooperating internationally without borders, without customs, without military forces. They can address the issues of the future without the global power play that we see going on at inter-governmental level. We have once more seen governments defending national interests rather than working together on a common global agenda. We suspect that the mechanisms, rules and routines of international diplomacy are outdated and incapable of designing and bringing about a sustainable future." [50]. 
Similar comments can be found from leading figures in the C40 Cities movement and other networks over the past decade, expressing dismay and frustration at inaction from national governments. Many leaders at this scale also present local governance bodies (above all, cities-see, for example, [51]) as the main agents of meaningful and responsible strategies and policy implementation for climate change mitigation and adaptation. However, despite the framing of local action as dynamic and innovative, as in the ICLEI statement above, it is clear that the development of many new local climate governance networks and institutions has been a unilateral response to MLG failures at 'higher' levels of policy making, and thus a compensatory, and far from optimal, partial governance innovation.

In this context, it is important to explore the emergent forms of local climate governance not only as potentially valuable innovations but also as developments that have been shaped faute de mieux by frustrated and determined local agents-not that local enthusiasm is any guarantee of coherent and capable follow-through in climate policy and effective governance innovations [38]. Patterson's [48] concept of institutional remaking is helpful in approaching the analysis of local emerging governance forms. This framework emphasises and offers a set of evaluative categories for description and assessment of local institutional forms that are evolving to cope with climate change and with the constraints and opportunities available in a given political and policy making context (see Table 1 below).

Table 1. Evaluation categories for institutional remaking [48].

\begin{tabular}{|c|c|c|c|c|}
\hline Category & $\begin{array}{l}\text { Description } \\
\text { Indicators }\end{array}$ & $\begin{array}{l}\text { Possible Empirical } \\
\text { Measures }\end{array}$ & Indicator & Type \\
\hline $\begin{array}{l}\text { 1. Comparative } \\
\text { improvement }\end{array}$ & $\begin{array}{l}\text { Substantive } \\
\text { improvements within a } \\
\text { given setting }\end{array}$ & $\begin{array}{l}\text { i. Within-case problem } \\
\text { solving } \\
\text { ii. Between-cases } \\
\text { problem solving }\end{array}$ & $\begin{array}{ll}\text { - } & \text { missions reductions } \\
\text { - } & \text { Risk reduction } \\
\text { - } & \text { Social equity } \\
\text { - } & \text { Legitimacy } \\
\text { - } & \text { Institutional 'fit' }\end{array}$ & Comparative \\
\hline $\begin{array}{l}\text { 2. Directionality of } \\
\text { institutional change }\end{array}$ & $\begin{array}{l}\text { Shaping the trajectory of } \\
\text { institutional } \\
\text { development }\end{array}$ & $\begin{array}{l}\text { i. Immediate shifts } \\
\text { ii. Shifts over time }\end{array}$ & $\begin{array}{ll}\text { - } & \text { Radical institutional change } \\
\text { - } & \text { Shifts in power and authority } \\
\text { - Cumulative and } \\
\text { catalytic effects }\end{array}$ & Temporal \\
\hline $\begin{array}{l}\text { 3. Capacity for } \\
\text { social action }\end{array}$ & $\begin{array}{l}\text { Ongoing capacity to } \\
\text { remake institutions } \\
\text { over time }\end{array}$ & $\begin{array}{l}\text { i. Capability } \\
\text { ii. Durability }\end{array}$ & $\begin{array}{ll} & \text { Agency } \\
- & \text { Opportunity structures } \\
-\quad & \text { Persistent changes in rules, } \\
& \text { with meaningful } \\
& \text { consequences }\end{array}$ & Generative \\
\hline
\end{tabular}

Source: [48].

Patterson's definition of institutional remaking reflects the importance of considering the evolution of climate governance as a process of improvisation and (re)invention of institutions in the face of constraining or failing wider institutional frameworks:

"Institutional remaking is defined here as: the activities by which agents intentionally develop political institutions in anticipation of, or in response to, institutional weaknesses and failures ... The term 'remaking' encompasses both the 'making' of new elements and the 'remaking' of existing elements, while emphasising that this (almost always) occurs within an existing (possibly already crowded) institutional setting [48] (p. 25), emphasis in original)".

This approach seems to fit well with our and others' analysis of the conditions of UK local governance in the face of climate change and of the development of national climate policy without a clear account of how it relates to the rest of the multi-level government system in the UK and to stakeholders in local governance. We return to this point in our concluding discussion below. 
The third theme we highlight from the literature is the lack of research to date on the micro-level of local climate governance. As noted above, the literature is dominated by studies of national, city and urban municipal governance, and there is much less attention to the smallest scales of local government and their partners in governance; a surprising situation considering the work of Ostrom [27,52,53] and the development of polycentric governance theory. In the multi-level system of the UK the parish and town council, and associated networks, constitute the lowest level of governance. We suggest that this is a potentially important level to investigate, as at the smallest scale of governance there is in principle a higher level of trust, contact and scope for civic engagement between citizens and representatives, and potentially a significant channel for transmission of information, practices and lessons learned between levels and actors in a multi-level governance system. We also suggest that in a multi-level or polycentric system, the kinds of problems affecting relations between national and sub-regional actors may be reproduced in new forms between the latter and the micro-level-as in the UK context, between county and district authorities on the one hand and their parish and town authorities on the other. We would expect to find evidence of Patterson's [48] institutional remaking in response, with new forms emerging at the micro-local level as well as among sub-regional levels (county and district/borough).

In light of this background analysis, this paper draws on an on-going research project that seeks to understand how sub-regional multi-level governance of urban and rural areas is adapting to climate change pressures and takes a case study approach to evaluate this within an English county (Surrey). The work maps the climate actions of Surrey's urban and rural councils following the UK's declaration of a national climate emergency in May 2019. Further, the analysis uses deductive coding, developed from the literature, to evaluate action by the various tiers of government and the change drivers underlying this activity. This allows us to consider the following questions: at the micro-local level is there evidence of collaboration and orchestration of governance; are we witnessing the remaking of institutions as suggested by Patterson [48]; and if micro-level climate governance is present does it conform to the features of MLG and PG outlined by Heinen et al. [6]. The implications of micro-level climate change governance are considered further in the discussion.

\section{Materials and Methods}

To address the questions raised in the introduction above, a case study research approach was considered appropriate due to the exploratory and explanatory nature of the work and as the knowledge base is still in development [54], with only limited research as yet into multi-level governance of climate crisis in the UK at the regional and local scales. The research aimed to map action by each tier of government within the selected area from May 2019 to the most recent point at which data were available. This would provide information that helped identify which governance bodies had declared climate emergencies, the type of action undertaken, and equally importantly highlight those who had taken little or no action.

This study has taken as its unit of analysis the climate action undertaken at different levels of sub-national government within one UK county, Surrey. The county provides a mixed peri-urban and rural area of some 1.2 million residents in the South-East of England, on the southern border of Greater London. Surrey is governed through multiple tiers of councils, a structure that is representative of many UK counties. The county council oversees the entire area, and within the county there are 11 borough or district councils and below this tier a range of town and parish councils. Surrey has no large cities but there are several significant towns, and a large part of the county is rural. Whilst mapping all Surrey Borough and District Council and sub-district government activity would provide an immensely rich and interconnected view of climate change action in Surrey, this was not feasible within the timeframe of the research. Instead it was decided to focus on one Borough, that of Waverley (see Appendix A for details of all councils within the study area). 
Waverley was selected as an example of a mixed urban-rural area, with high emissions. The borough covers $345.2 \mathrm{~km}^{2}$ and is, along with several other Surrey boroughs, highly prosperous overall, and ranked second in the UK in a recent think-tank ranking of affluence [55]. It has 121,572 residents [56]. Recent carbon footprint baseline work [57] by the University of Surrey for the independent Surrey Climate Commission identified Waverley emitting $522 \mathrm{ktCO} 2$ in 2018, approximately $9 \%$ of the country's overall emissions. Emissions attributable to commuting and use of 'other' fuels are higher in this borough than any other, but its rural nature also supports one of the highest levels of carbon sequestration [58] The borough is divided into 21 civil parishes, of which three are town councils and the remainder are represented by parish councils (See Annex A for list). The three towns have a combined urban population of 78,118 , with the smallest town having a population of 16,000. By contrast, the parish councils in Waverley represent much smaller numbers: the smallest has 185 residents, whereas there are over 11,000 people in the parish of Cranleigh [56]. Most parishes are rural. Waverley ranks highly on measures of social capital, both in terms of family and social networks as well as exhibiting trust in institutions and suggesting high levels of civic engagement [55].

Data for analysis were derived from council minutes, population statistics [59,60] and the nature of the council area in terms of its urban, urban/rural or rural nature. Council minutes were selected as suitable for this exploratory phase as they offered a standardized form of reporting on council activity, at all tiers. Indeed, all council types are required by UK law $[61,62]$ to publish minutes of formal meetings not later than one month after the date of the meeting. Minutes and supporting documents are available for at least six years after publication [61], and whilst still available in paper format most are digitised. Such minutes offer detailed and factual notes which were easily accessible online. However, it should also be noted that the depth of information recorded can vary that such minutes are likely to exhibit a level of reporting bias and omissions [55]. Full council meetings and, where available, relevant sub-committees' minutes at each tier of government were utilised. All councils within this review had websites and provided online open access to all council minutes, with the exception of Peper Harow, the smallest parish in the sample. Due to the difficulties of accessing paper copies during the COVID period Peper Harow is not included in the analysis. Frequency of council meetings varies from monthly, often excluding August, to bi-monthly. More specific committees such as transport, health finance or planning were not reviewed, although these topics were frequently covered at sub-county council meetings. The mapping exercise defined the timescale over which the area is being studied. Whilst a national climate emergency had been declared in May 2019 the starting point for more detailed review was based on the slightly later climate emergency declaration by Surrey County Council in July 2019 [58]. The end date of the longitudinal study was April 2021, the last date for which minutes were available during our research period.

All minutes were read in full to ensure that all relevant text was identified, an important issue where climate change material is characterised by multiple key words, across many issues. Local parish websites and online news articles were additionally reviewed and where climate change was highlighted the text was also recorded. All text was logged, firstly in Microsoft Excel and then transposed into Nvivo (Version 12) for further textual analysis. During the mapping phase all text was categorised by nature of the activity, and these categories are presented in Table 2. The output from this work was a Microsoft Excel table (Table 2) providing a longitudinal analysis of the nature of climate action by county council, Waverley Borough and all town and parish councils within this borough. It should also be noted that to improve the presentation of the material rather than reference the minutes of each council within the text, the online source of the material is acknowledged in Appendix C.

To provide a richer understanding of the underlying drivers or nature of climate action, further textual analysis was undertaken using Nvivo 12 to support a deductive coding process. Deductive codes were drawn from the literature and a coding structure is 
provided in Appendix B. All resulting material was then assessed by both researchers and the findings discussed and evaluated.

\section{Results}

Council minutes were successfully accessed for all councils within the unit of analysis. Of the 23 councils comprising this case study, $73 \%$ of the councils included climate change issues within their meeting records, with five parish councils making no reference to climate change (see Table 2). Only $45 \%$ of councils are observed taking any climate action. Both the County Council and Borough Council record a wide range of activity, creating climate strategies, taking action, collaborating and developing action plans. Waverley also appear provide a key dissemination function in providing parishes with Borough Council climate action, with more than $60 \%$ of the parishes noting this in their minutes. It is clear that links to County Council work on climate are much more limited at this sub-borough level, with only three parishes detailing this in their notes. Only one, Cranleigh, mentions national government, and this shortly after the declaration of the national climate emergency. Similar to the Borough, the minutes of all three town councils suggest they are strongly engaged with the issue, although the records from Farnham suggest lower activity levels than their peers. We observe five parishes who have primarily incorporated climate into sub-committee work, are taking action, communicating climate change and collaborating with others. Two parishes have taken limited action, or worked more collaboratively with more climate active parish councils. Finally, five parishes have recorded a discussion of climate change in the context of updates from the Borough or County Council representative but appear to have taken no action. There is no indication in council minutes that the work being undertaken is attempting to achieve specific local goals, co-ordinated horizontally across peer groups or vertically at different governance levels. This includes direct contributions towards the achievement of the Waverley Boroughs Climate Action plan.

\subsection{General Observations}

The longitudinal nature of the data provides insight into the flow of information and timescale of engagement. The results of the analysis confirm that the county council, borough and town councils all declared climate emergencies within four months of the UK Government's national declaration, with only two parish councils since taking a similar stance (see Table 2). As highlighted in Section 1.1, such declarations are not mandated by government but represent a response to local stimuli, either internal or external to the council. Whilst it is clear in Table 2 that the first COVID lockdown forced a pause in activity, those councils most engaged with the subject have continued to embed climate activity, at a range of scales, within their policy processes.

For parish councils, Waverley Borough Council members appear to be a main source of climate governance information, with climate emergency declarations being included in their briefings to the local parish councils in the period September-December 2019. Updates were then undertaken in 2020 at the launch of their carbon neutrality action plan, even though recognising that 'targets are still thin and costs lacking' (Dunsfold PC). National climate action receives little mention, with only Cranleigh parish council highlighting the government climate emergency declaration in July 2019. Similarly, few councils mention the work of Surrey County Council in relation to climate policy. The three town councils have no direct climate change references to other governmental sources. 
Table 2. An analysis of climate action by sub-national councils within borough of Waverley, July 2019-April 2021 (see Appendix C for links to source materials).

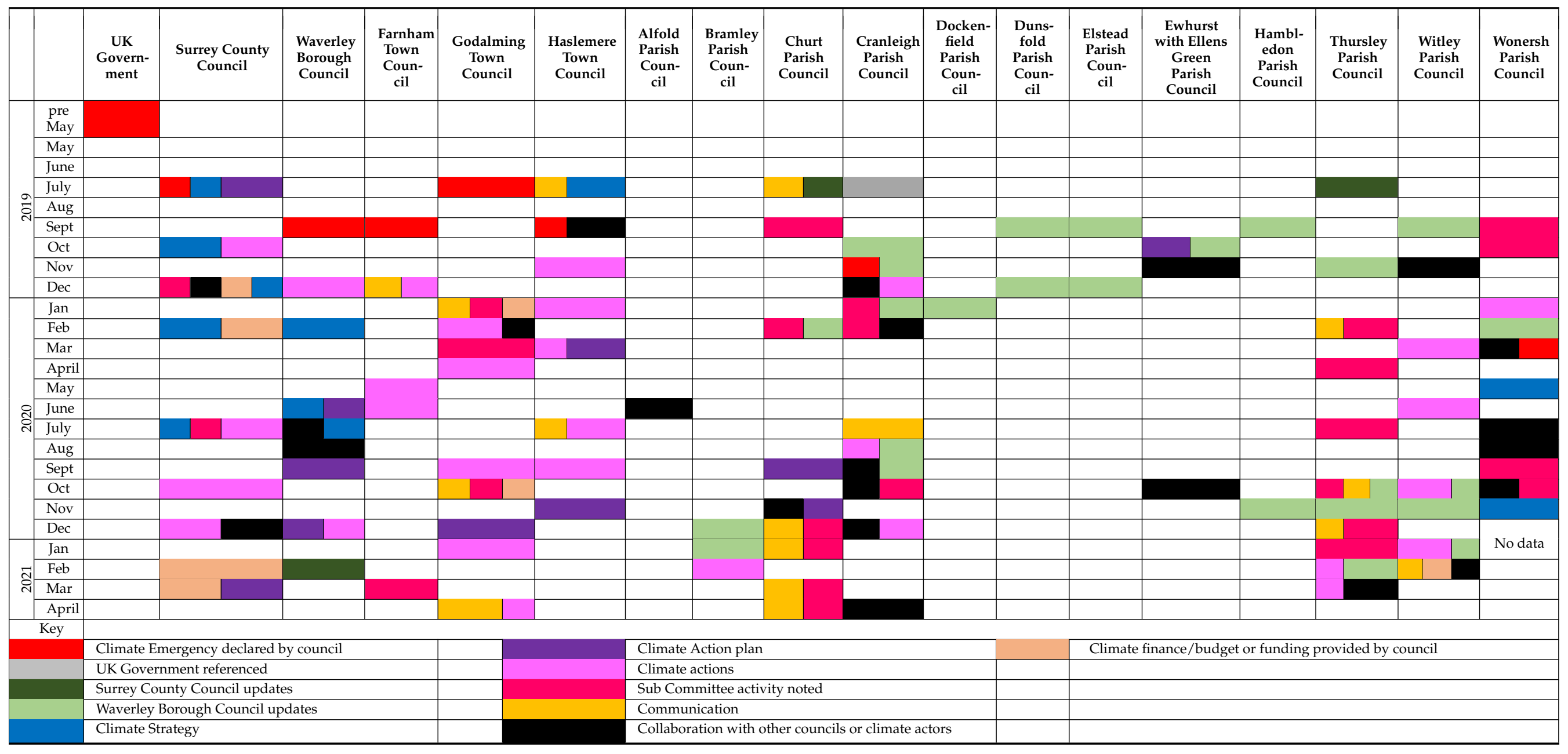




\subsection{Size of Governance Unit}

Much of the work on polycentric governance highlights the importance of ground-up, local initiatives generating collective action [63]; yet this exploratory study suggests that a small population may not generate public body-led action. Based on Table 2 councils were ranked as high, low, information-only or none in terms of the governance activity they have undertaken since the UK National climate emergency declaration. As is clear from the categorisation of activity these categories do not indicate effective climate outcomes. Due to the difference in population size and governance structure, town and parish councils were represented separately. The results, illustrated in Table 3, suggest there may be an alignment between population size and the level of climate governance activity (see Annex A for council by size ranking). Here, the divide appears to be less about urban and urban/rural council areas. We also see at least two councils with small populations ostensibly outperforming other larger population areas.

Table 3. Towns and councils by level of climate governance activity.

\begin{tabular}{cccc}
\hline $\begin{array}{c}\text { Level of Climate } \\
\text { Governance Activity }\end{array}$ & Total Population & $\begin{array}{c}\text { Average Pop./ } \\
\text { Council Area }\end{array}$ & $\begin{array}{c}\text { Council Size } \\
\text { Ranking by Type }\end{array}$ \\
\hline High (Town Council) & 78,118 & 26,039 & $1,2,3$ \\
High (Parish Council) & 24,636 & 4927 & $1,2,4,10,15$ \\
Low (Parish Council) & 5950 & 2975 & 3,7 \\
Info only (Parish Council) & 6426 & 1285 & $6,9,11,12,16$ \\
None (Parish Council) & 6719 & 1120 & $5,8,13,14,17,18$ \\
\hline
\end{tabular}

When level of climate governance activity is plotted across Waverley Borough parishes (see Figure 1), we see two geographical clusters emerging. Godalming, which declared a climate emergency in July 2019 and is highly active, forms an intersection between the two areas of high/low activity.

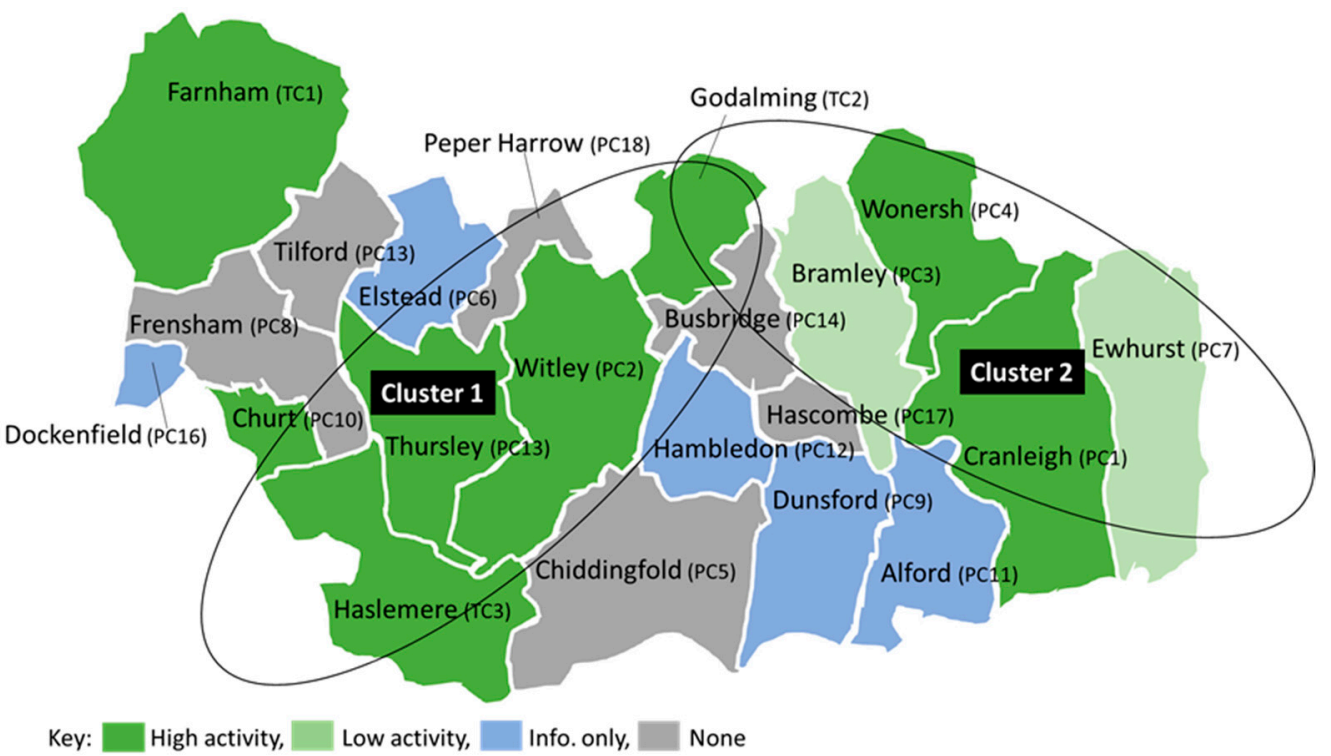

Figure 1. Levels of climate governance activity by parish.

This may suggest that smaller parishes such as Churt (PC10) and Thursley (PC15) in Cluster 1 may be influenced or supported by neighbouring parishes into greater activity than population size trends would indicate. Here, we may be witnessing an example of co-ordination or collaboration at a horizontal level. In contrast, in Cluster 2, Bramley (PC3) and Ewhurst and Ewell (PC7) are not performing as strongly as would be expected in 
terms of their population size. Further assessment of the minutes was then undertaken to further draw out any indication of collaborative working. From this, a more nuanced picture emerges.

\subsection{Knowledge Acquisition and Local Collaboration}

Whilst minutes of council meetings are not sufficient to draw out complex interactions and relationships between individuals, this on-going research has been able to identify several routes by which inter-council collaboration and knowledge exchange have occurred.

Waverley Borough Council was seen by parish and town council members as a local leader, with their proposal of a 2030 net zero target (Haslemere TC) and their key role in dissemination of information. Leading councillors acknowledged a divide between small rural parish and town engagement and identified that 'it was important for the villages to be involved in the discussions rather than just the larger towns' (Waverley BC). Godalming and Cranleigh appear to be acting as local leaders at the sub-borough level. Godalming took an early lead in declaring a climate emergency, have set up working groups, and have taken action to offer financial support to local climate groups. Cranleigh has also been highly active in seeking external information and knowledge, looking to work with the University of Surrey, undertaking testing work on the University of Exeter carbon footprint tool, undertaking site visits and organising a Climate Change Event. Both of these councils have supported others in the borough, with Haslemere seeking guidance on criteria setting for environmental grants, a councillor providing information at a Churt PC meeting in February 2020 and Ewhurst linking to Cranleigh's repair café campaign (see Figure 2).

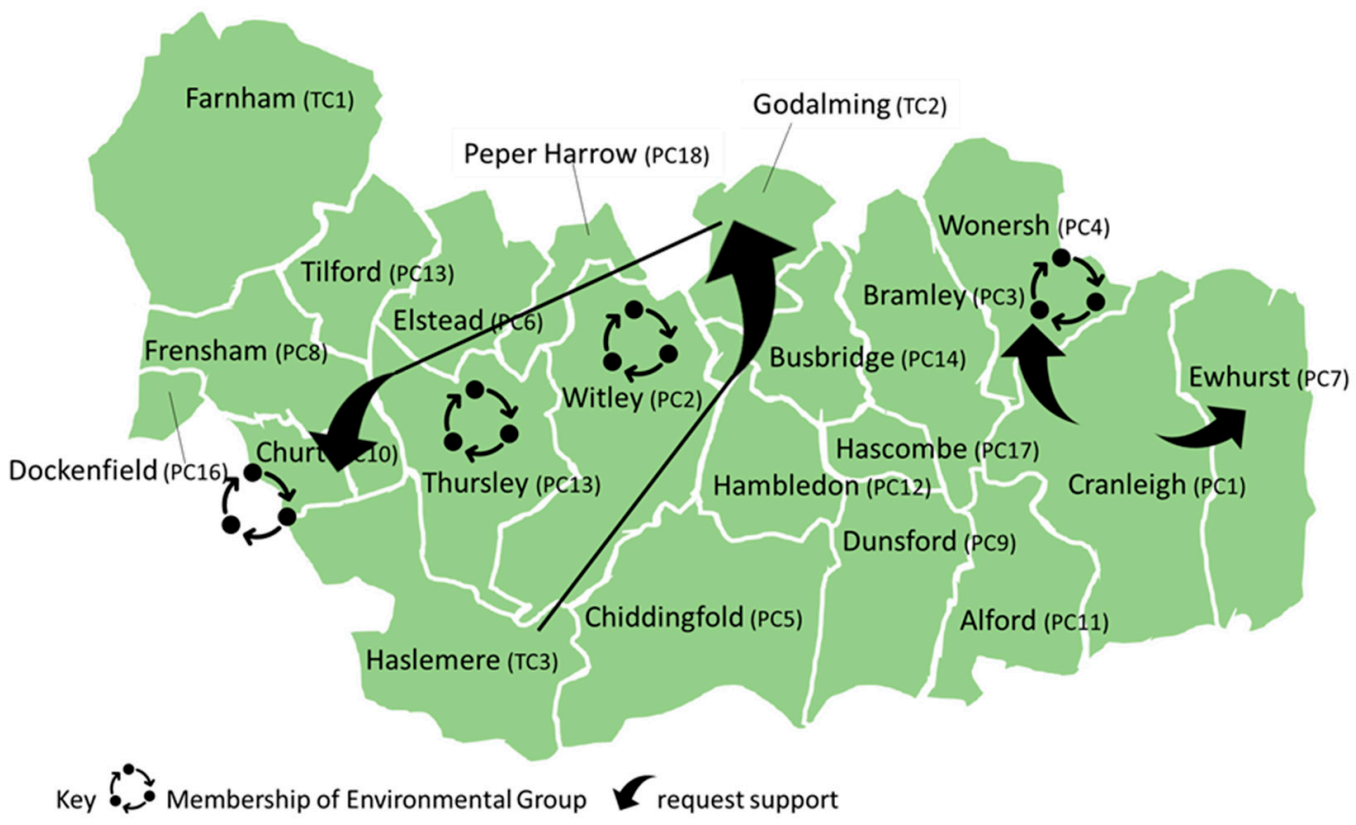

Figure 2. Collaborative engagement.

We also see the beginnings of engaged parishes beginning to develop collaborative working. As noted above, Cranleigh hosted an event delivered by the Centre for Sustainable Energy which involved local stakeholders from all tiers of Government. The discussion placed 'an emphasis upon the role of parish and town councils in enabling purchasing and behaviour change, drawing upon sustainable development goals' (Wonersh PC). The Churt PC representative noted a low attendance by neighbouring parishes but felt the event had led to 'a good dialogue with a councillor from Thursley PC who is actively engaging the public in Thursley' (Churt PC). More recently, a multi-parish environmental group has formed, something that was in discussion in March 2021, when minutes noted that councillors 'had spoken to Witley Parish Council who are in the early stages of their 
discussions on the matter but that a multi-parish collaboration arrangement had been discussed.' (Thursley PC).

Whilst it is clear that many of the parishes primarily rely on Waverley Borough Council for governance updates, councils across the borough appear to draw on their councillor's knowledge of external organisations for climate guidance and information. Rural parish councils exhibit strong links with biodiversity and land-based organisations, such as Plantlife, Butterfly Conservation and the Surrey Hills Management plan. Town and borough councils appear to reflect a more urban focus, with recommendations to seek information from the Energy Saving Trust and the Carbon Savings Trust on electric vehicles. Three organisations- the Friends of the Earth [63], the Centre for Sustainable Energy (CSE) and the Local Government Association-offer specific climate change guidance for subregional councils, with CSE holding a conference for the borough councillors, and then for clerks, in 2020. This localised approach-although events seem to have been poorly attended-was felt to offer valuable learning and opportunities for collaboration (Thursley PC) and new initiatives (Haslemere TC). The research also reveals council interaction with business as a source of knowledge, with councillors attending a presentation on zero carbon homes and others visiting the site of a biodigester and community composting.

Understanding the measurement of carbon and learning how to set baselines are much less explored in debates and exchanges at the parish and town levels. With the exception of the county council, only two councils in the Waverley area, Godalming TC and Cranleigh PC, have considered or implemented carbon footprinting. Cranleigh seems to have been particularly proactive, working with the University of Exeter as one of 170 parishes testing a new community carbon footprint tool; IMPACT [64]. They have additionally looked to the local University of Surrey for student support in developing their strategy.

Such engagement with academic and research institutions appears unusual at a subregional level, although the county council does include University experts in advisory boards and commissions research projects. More generally, Surrey County Council officers are working through the Surrey Association of Local Councils (SALC) and the professional body for council clerks (SLCC) 'to establish best practices protocols for reporting environmental implications of recommendations and setting baselines. (Surrey CC). It should also be noted that there was no indication of any online platform for sharing learnings or experience across the borough or county.

\section{4. 'Wilful' Actors}

In trying to understand why parishes and boroughs have developed new forms of governance to support action on the climate emergency, our research, so far, suggests that 'wilful' actors have played a role. We define these as local policy actors who have initiated 'do-it-yourself' action in the absence of support, guidance or leadership from higher levels of governance: they can be seen as local agents in the institutional remaking process analysed by Patterson (2021) and noted above.

Three types of 'wilful' actors have been identified in the analysis to date:

- $\quad$ unaffiliated local resident(s);

- A resident member of an environmental group;

- A climate-engaged council member.

Such actors attending meetings and putting pressure on councils to act appear to be most dynamic at a town and borough level.

The most frequently recorded actors of this kind are those representing environmental groups, most of which are specific to the area or act as local elements of global organisations. At the most local level, a newly formed residents environmental working group in Churt to Plastic Free Farnham and Plastic Free Godalming. Haslemere residents appear to be particularly active with representation from the Sustainable Business Initiative, a residents' group; and from the Haslemere Climate Alliance, Transition Haslemere and a representative from the Eco-Church movement of the Diocese of Guildford, all in favour of a climate emergency declaration. Extinction Rebellion members are linked with three council climate 
debates, including Surrey County Council, which experienced extensive group pressure. In Godalming, council members were challenged by a member of Friends of the Earth on deployment of solar panels.

Independent resident voices appear less frequently, but certainly at a parish level are important, raising practical changes such the introduction of electric vehicle charging points and street lighting switch-off policies (Bramley PC). Residents attending council meetings in Farnham, Godalming and Haslemere supported climate emergency declarations, and in Haslemere were backed by a 600-signature petition. Less visible through council minutes are individual councillors who are not just interested and support climate change, but who push for action and drive change. This is seen particularly strongly in Churt, with the Parish Clerk inviting the Centre for Sustainable Energy to present to the Surrey parish clerks and in the development of a Climate net zero website for the parish by the Environment Portfolio holder. At a county level, the councillor representing the Green Party offers both support and challenge to Surrey County Council.

\subsection{Finance}

The research identifies the importance placed by sub-regional councils on the role of the UK government in supporting climate change action; it is 'essential for central government to provide powers, funding and other resources' (Farnham TC). This is echoed at borough and county levels, aligned to concerns of local service trade-offs: 'to be able to secure funding from the government for this strategy rather than use funding that his currently supporting vulnerable Waverley residents' (Elstead PC). Our work, so far, on Surrey also indicates that, at the borough level, councils are lobbying local MPs to support 'the provision of necessary powers and resources to enable all UK local authorities to achieve carbon neutrality by 2030' (Waverley BC). At the county level, 'the Council's credibility on addressing climate change was dependent on significant investment, strengthened dialogue with Local Enterprise Partnerships and the Government' (Surrey CC). Surrey County Council officers have identified, through work by the University of Leeds and the University of Surrey, a requirement of approximately $£ 1$ billion in investments to enable the net zero transition and related environmental policies in the county (Surrey CC).

Even though local parishes have very limited budgets, there was at least one example of grant funding being allocated to tree planting, and other two parishes collaborated to raise over $£ 20,000$ for fire damage to a local heath. Both Godalming and Haslemere TC's have set up small green grant schemes, supporting carbon reduction projects and basing value for money on the amount of carbon saved per pound awarded. One small Godalming grant of $£ 3000$ for a cycle way feasibility study resulted in $£ 200,000$ of Strategic Community Infrastructure Levy funding to undertake the work. Waverley BC have incorporated carbon reduction requirements into their procurement process. Funding is being allocated at a county council level, such as $£ 49$ million for Surrey Ultra-low and Zero Emissions schemes, $£ 32$ million to remove polluting buses and $£ 6.3$ million for community transport. Concerning the County Council's $£ 100 \mathrm{~m}$ Community Investment Fund launch, councillor feedback noted that the fund was to be used to support 'meaningful projects in local communities-not solely restricted to climate change' (Surrey CC). There was no indication whether or how funding would be allocated at a more localised level for parishes and towns, or for local networks.

\subsection{Orchestration and Subsidiarity}

The research, so far, has found no examples that climate change governance was being orchestrated across the multiple tiers of councils reviewed. While Waverley Borough councillors did provide updates to parishes on the climate emergency, this did not appear to be linked to any management of response or action. Reference to the UK government's climate strategy was extremely limited, and this suggests that, at the sub-regional borough and parish levels, there is no element of subsidiarity in climate action. Even with some 
examples of collaborative activity, there is no indication that actions are being focused and coordinated to maximise impact.

\section{Discussion}

This research forms part of a wider on-going project on the remaking of local governance in the face of climate change, and offers an initial insight into the role and activities of multiple tiers of sub-national government, from county to micro-level government action on climate change in the UK. It sits within the policy context set by a national government which has had (so far) a highly centralised approach to climate change, with no binding targets or mandates on carbon reduction or climate action beyond the devolved nations of the UK (Scotland, Wales, Northern Ireland) [65]. Additionally, its Ten Point Plan for a Green Industrial Revolution [43] focuses primarily on top-down, techno-centric solutions. Indeed, recent submissions to the Environment Audit Committee of the House of Commons in the UK Parliament, for its inquiry into local government and net zero climate policy (July and August, 2021), emphasise the lack of a sub-national framework for net zero transition and of a long-term plan for local climate mitigation and adaptation funding. This is despite clear guidance from the Committee on Climate Change [42] and their acknowledgement that:

'More than half of the emissions cuts needed rely on people and businesses taking up low-carbon solutions-decisions that are made at a local and individual level'. [42] (p. 3).

From our findings to date based on parish, town, district and county council minutes in Surrey, we would concur that there is little evidence of sub-national climate action inspired and facilitated by national government. To put it another way, there remains little clarity about what the division of labour should be between different actors in the multi-level system in relation to climate action: the UK lacks a 'climate constitution' debate and process, although there is no lack of calls for such systematic thinking and action about national-local relations for climate policy [37-45].

We suggest that climate issues need to be understood within the broader concerns and problems, as noted in Section 1 above, concerning the overall relationship between central and sub-national governments in the UK [32]: the UK has an uneasy quasi-federal system based on devolution of powers to constituent sub-nations (Scotland, Wales and Northern Ireland), whose population and economic weight are dwarfed by England. The latter sub-nation has a multi-level local government system that lacks a regional tier of government and that is a patchwork of diverse sub-regional authorities and governance networks. The system is 'polycentric' in form but in practice highly centralised in resource generation and allocation [66]; it lacks a subsidiarity approach similar to that adopted as an ideal by the European Union, in which powers are devolved to the lowest level appropriate for effective policy making depending on policy domain.

We also failed to find, so far, any examples of systematic orchestration of climate action across the levels of local governance in the county. The gaps and weaknesses in the overall framework are criticised by local government and governance actors, pointing to centralism and lack of policy coherence. Such criticisms have been reiterated in relation to the centralisation of climate policy to date, and to its lack of attention to implementation of mitigation and adaptation at sub-national scales $[24,37,38,42,44]$. This critique is certain to be elaborated in a forthcoming report on local government's role in net zero policy making and delivery, from the Environmental Audit Committee of the House of Commons.

Pending changes in the wake of that report and similar calls for reform, and pending the UK Government's promised action plan for net zero, which might give some clarity about multi-level climate governance, local actors in areas such as Surrey have been 'remaking' institutional arrangements in the absence of substantial central guidance and support, and in the face of limited provision of information and time-limited grants. Government has provided modelled national statistics emissions data for counties and boroughs/districts so they can understand their carbon footprint but offered no target other than the national, legally binding, 2050 net zero goal [67]. As with Howarth [38], we found the primary focus of sub-county activity to be focused on mitigation actions only. 
The UK Parliament's declaration of a climate emergency, whilst world leading and dramatic, did not create a legally binding commitment to comply or act, at any level of government. However, this action, and the accompanying publicity and activism, did seem to help prompt autonomous action at the local scale: in our research, we observe declarations of climate emergencies at multiple levels of sub-national government in Surrey, as a result of local decision making (see also [38]). Indeed, many of these were supported by the actions of local 'wilful actors'. Our case study reveals considerable action being undertaken at local and micro-local levels, with many town and parish councils independently taking steps to support climate goals. The analysis suggests, however, that many of these are working in isolation with little guidance on how they should act.

We also find only limited flows of information downwards across levels of government and even less flowing upwards from a parish level. Overall, sub-national actors such as the county council and districts and boroughs are critical of the lack of 'visibility' of climate guidance, resources and coherence above them in the governance hierarchy; and for microlevel actors the actions, division of labour and resources for climate policy are largely 'invisible' at the upper local scale as well as the national one. Problems of incoherence and lack of orchestration are thus repeated from one scale of relationships (national/county) to the others (county/district/micro-local), and independent action at the local scales is constrained by resources and capabilities.

All this is consistent with our analysis above of the nature of multi-level climate governance in the UK as a case of local institutional 'remaking' [48], in the face of both a policy imperative and a policy vacuum as to how climate policy is to be developed and implemented at sub-national scales. The remaking of existing processes and institutions and the creation of new ones are reflections both of urgency and local commitment on the one hand, and frustration on the other. As noted earlier, local climate governance in the current UK framework is largely improvisatory and compensatory, and with that comes risks of incoherence, ineffectual action and confusion. In particular, micro-local action, in the absence of clarity about tasks and resources, risks being ineffective and fragmented, for all the enthusiasm and energy we have detected in fieldwork in parish and town council networks.

Whilst there are nascent elements of promising multi-level climate governance, such as borough councils co-ordinating with parishes, town councils setting up funds (Godalming and Haslemere) and NGOs and business collaborating at a county level, current governance appears to be closer to the fragmented typology created by Pahl-Wostl and Knieper [68] which lacks the ordering and co-ordination [69] and distribution of power [68] needed for effective multi-level or polycentric governance.

In the absence of a clear and coherent division of policy labour within a multi-level framework, potential for action at county, district/borough and micro-local level is not likely to be harnessed and realised effectively and consistently. In particular, our research, so far, suggests that the county level and the borough are more active than the parish and town councils. At the micro-local level, our analysis suggests that this may be an issue of scale, but this needs to be investigated further as funding, capacity, regulatory alignment and other factors are also likely to play a role. We may also be observing differences between urban and rural interests and needs. Further work may give insights into what would constitute the most effective set of roles for micro-local actors and also the limits to their climate activities.

\section{Conclusions}

Climate governance- the development and implementation of coherent and effective policy for decarbonisation and adaptation by government actors and their governance partners at all levels from national to micro-local-is an emerging and, so far, ill-specified set of institutional forms in the UK. We have set out the context in which local climate governance arrangements are evolving in the UK, and related them to major themes in the literature on climate, multi-level governance and polycentrism. 
It may be that the issues we have identified in local climate governance in our case study area have much wider resonance internationally, notably in similarly centralized states where local and regional actors lack adequate resources, recognition and clarity of division of labour concerning climate action. These issues raise questions of major concern for our theoretical and practical understandings of urgent and ambitious climate action within a multi-level governance framework. What would constitute an effective division of labour for climate action between national and sub-national levels? How can this be related to wider frameworks of governance for sustainability? What is the role in climate action of the sub-regional levels of governance, from (in the UK context) county to micro-local actors? What processes would generate a more effective orchestration of action? Additionally, what are the features of sub-national climate action in the absence of a systematic attempt at answering these questions by policy makers?

Whilst this study has been able to identify micro-level action, begin to understand some of the underlying causes and consider these within current theoretical approaches, it does have limitations. The use of council minutes offers only an imperfect insight into the motivations behind action, are likely to offer a level of bias within the reporting, and fail to capture all the work being undertaken at this sub-national level. It is also inherent within a case study approach that it remains difficult to generalize the findings beyond the area of study. Further research is needed to address the questions raised above. Our on-going research in the English county of Surrey indicates that a process of improvisatory and compensatory innovation is under way in climate governance at the level of the county, districts and boroughs, and among the micro-level bodies at the parish and town scales. This is consistent with Patterson's [48] analysis of the need for a 'remaking' of institutions for climate action in a context of wider institutional failure and inadequacy. We suggest that a wider programme of sub-regional research will shed further light on this uneven process across the UK, as local government bodies and their partners respond to the climate crisis in the absence of a clear multi-level 'settlement' that enables truly effective divisions of mitigation and adaption labour, and an approach to multi-level governance that plays to the strengths of each level of governance actors.

Author Contributions: All authors have been involved in the conceptualisation, research, development, writing and reviewing of this paper. All authors have read and agreed to the published version of the manuscript.

Funding: The authors gratefully acknowledge the support from the UK Economic and Social Research Council through the Place-Based Climate Action Network (P-CAN) (Ref. ES/S008381/1).

Institutional Review Board Statement: The study was conducted according to the guidelines of the Declaration of Helsinki, and the Ethical Review self-assessment process of the University of Surrey was followed.

Informed Consent Statement: Informed consent was obtained from all subjects involved in the study.

Acknowledgments: We gratefully acknowledge financial support from the UK's Economic and Social Research Council (ESRC) through the Place- based Climate Action Network (PCAN).

Conflicts of Interest: The authors declare no conflict of interest.

\section{Appendix A}

Table A1. Multi-level government in Surrey: the case of Waverley district.

\begin{tabular}{|c|c|c|c|c|c|}
\hline Type of Council & Name of Council & $\begin{array}{c}\text { Area Covered } \\
\left(\mathrm{km}^{2}\right)\end{array}$ & $\begin{array}{l}\text { No. of People } \\
\text { Represented }\end{array}$ & $\begin{array}{c}\text { Primary } \\
\text { Nature of Area }\end{array}$ & $\begin{array}{c}\text { Ranking by Size of Population } \\
\text { (TC = Town Council, } \\
\text { PC = Parish Council) }\end{array}$ \\
\hline County Council & Surrey & 166.3 & $1,132,400$ & Urban/rural & \\
\hline Borough Council & Waverley & 345.2 & 12,752 & Urban/rural & \\
\hline
\end{tabular}


Table A1. Cont.

\begin{tabular}{|c|c|c|c|c|c|}
\hline Type of Council & Name of Council & $\begin{array}{c}\text { Area Covered } \\
\left(\mathrm{km}^{2}\right)\end{array}$ & $\begin{array}{l}\text { No. of People } \\
\text { Represented }\end{array}$ & $\begin{array}{c}\text { Primary } \\
\text { Nature of Area }\end{array}$ & $\begin{array}{c}\text { Ranking by Size of Population } \\
\text { (TC = Town Council, } \\
\text { PC = Parish Council) }\end{array}$ \\
\hline \multirow{3}{*}{ Town Council } & Farnham & 36.52 & 39,488 & Urban & TC1 \\
\hline & Godalming & 9.68 & 21,804 & Urban & TC2 \\
\hline & Hazelmere & 23.27 & 16,826 & Urban & TC3 \\
\hline \multirow{18}{*}{ Parish Council } & Alford & 15.1 & 1059 & Rural & PC11 \\
\hline & Bramley & 18.87 & 3559 & Rural & PC3 \\
\hline & Busbridge & 9.92 & 779 & Rural & PC14 \\
\hline & Chiddingfold & 28.18 & 2960 & Rural & PC5 \\
\hline & Churt & 4.68 & 1202 & Rural & PC10 \\
\hline & Cranleigh & 32.78 & 11,241 & Urban/rural & PC1 \\
\hline & Dockenfield & 2.73 & 399 & Rural & PC16 \\
\hline & Dunsford & 9.89 & 1606 & Rural & PC9 \\
\hline & Elstead & 11.04 & 2557 & Rural & PC6 \\
\hline & $\begin{array}{l}\text { Ewhurst with } \\
\text { Ellens Green }\end{array}$ & 23.79 & 2391 & Rural & PC7 \\
\hline & Frensham & 16.21 & 1689 & Rural & PC8 \\
\hline & Hambledon & 11.11 & 805 & Rural & PC12 \\
\hline & Hascombe & 5.25 & 307 & Rural & PC17 \\
\hline & Peper Harrow & 5.34 & 185 & Rural & PC18 \\
\hline & Thursley & 19.85 & 651 & Rural & PC15 \\
\hline & Tilford & 9.87 & 799 & Rural & PC13 \\
\hline & Witley & 27.76 & 8130 & Rural & PC2 \\
\hline & Wonersh & 17.78 & 3412 & Rural & PC4 \\
\hline
\end{tabular}

\section{Appendix B}

Table A2. NVIVO Coding utilised for the review of council minutes.

\section{Deductive Codes}

Climate Action Taken

Co-benefits

Collaboration

Communication

Finance

Orchestration

Sub-national Surrey

knowledge

\section{Minutes-Council Meetings}

All activity recorded-includes development of plans and strategy, working group set up, local action to support carbon reduction or co-benefits (note further inductive coding to identify specific actions)

Additional benefits derived from taking climate change action

Choosing to work with others; to support or learn from climate change goals

Providing information to the public or acknowledging community engagement

Climate change and budget requirements, addressing climate change in budgets, local funding

Direct management of multi-level governance for climate change

How knowledge is being acquired by local government actors 
Table A2. Cont.

\begin{tabular}{ll}
\hline \multicolumn{1}{c}{ Deductive Codes } & Minutes-Council Meetings \\
\hline Subsidiarity & allocation of roles to sub-national government bodies to support global or national climate change goals \\
\hline Urban-rural & Note or comment on different status between areas \\
\hline Wilful Actors & Individuals who are challenging the status quo or driving climate action \\
\hline
\end{tabular}

\section{Appendix C}

Table A3. Acknowledgement of the source of council minutes.

\begin{tabular}{|c|c|c|}
\hline Type of Council & Name of Council & Online Source of Council Minutes \\
\hline County Council & Surrey & https://mycouncil.surreycc.gov.uk/ieListMeetings.aspx?CId=121\&Year=0 \\
\hline Borough Council & Waverley & https://modgov.waverley.gov.uk/ieListMeetings.aspx?CId=130\&Year=0 \\
\hline \multirow{3}{*}{ Town Council } & Farnham & https:/ / democracy.farnham.gov.uk/ieListMeetings.aspx?CId=1137\&Year=0 \\
\hline & Godalming & https://godalming-tc.gov.uk/agendas-minutes/agendas-minutes-2020/ \\
\hline & Hazelmere & $\begin{array}{l}\text { https://haslemeretc.org/meetings/ } \\
\text { Archive: https://haslemeretc.org/categories/minutes-archives/ }\end{array}$ \\
\hline \multirow{18}{*}{ Parish Council } & Alford & http://alfoldparishcouncil.co.uk/index.php/minutes/ \\
\hline & Bramley & $\begin{array}{l}\text { https://www.bramleyparish.co.uk/community/bramley-parish-council-15042/ } \\
\text { meeting-minutes/\# }\end{array}$ \\
\hline & Busbridge & https://www.busbridgeparishcouncil.org.uk/meetings \\
\hline & Chiddingfold & https://chiddingfold-pc.gov.uk/parish-council-minutes/ \\
\hline & Churt & https://www.churt.org/council-agendas-and-minutes \\
\hline & Cranleigh & https://www.cranleigh-pc.gov.uk/Full_Council_15104.aspx \\
\hline & Dockenfield & http:/ /www.dockenfieldpc.org.uk/meetings.html \\
\hline & Dunsford & https://dunsfoldparishcouncil.gov.uk/document-category/minutes/ \\
\hline & Elstead & https://elsteadvillage.co.uk/parish-council-meetings/ \\
\hline & $\begin{array}{l}\text { Ewhurst with } \\
\text { Ellens Green }\end{array}$ & https://www.ewhurstellensgreen-pc.gov.uk/agendas--minutes.html \\
\hline & Frensham & https://www.frensham-pc.gov.uk/Full_Council_30315.aspx \\
\hline & Hambledon & https://www.hambledon-pc.gov.uk/Parish_Council/Parish_Council_Meetings.aspx \\
\hline & Hascombe & https://www.hascombeparishcouncil.co.uk/new-page \\
\hline & Peper Harrow & Not available online-no website \\
\hline & Thursley & https://www.thursley-pc.gov.uk/Minutes.aspx \\
\hline & Tilford & http:/ / www.tilfordpc.org.uk/meetings.php?id=15 \\
\hline & Witley & https://witley-pc.gov.uk/parish-council/meetings-minutes/ \\
\hline & Wonersh & https://www.wonershparish.org/our-meetings \\
\hline
\end{tabular}




\section{References}

1. Abbott, K.W.; Bernstein, S.; Janzwood, A. Orchestration. In Architectures of Earth System Governance: Institutional Complexity and Structural Transformation; Biermann, F., Kim, R., Eds.; Cambridge University Press: Cambridge, UK, 2020; pp. $233-253$.

2. Bulkeley, H. Accomplishing Climate Governance; Cambridge University Press: Cambridge, UK, 2016.

3. Dubash, N.K. Varieties of climate governance: The emergence and functioning of climate institutions. Environ. Politics 2021, 30, 1-25. [CrossRef]

4. Hamman, P. (Ed.) Rethinking Hierarchy in Sustainability Governance: A Literature Review. In Sustainability Governance and Hierarchy; Routledge: Abingdon, UK, 2019.

5. Harris, P.G. Pathologies of Climate Governance: International Relations, National Politics and Human Nature; Cambridge University Press: Cambridge, UK, 2021.

6. Heinen, D.; Arlati, A.; Knieling, J. Five dimensions of climate governance: A framework for empirical research based on polycentric and multi-level governance perspectives. Environ. Policy Gov. 2021, 31. [CrossRef]

7. Wurzel, R.K.; Liefferink, D.; Torney, D. Pioneers, leaders and followers in multilevel and polycentric climate governance. Environ. Politics 2018, 28, 1-21. [CrossRef]

8. Adger, W.N.; Jordan, A. (Eds.) Governing Sustainability; Cambridge University Press: Cambridge, UK, 2009.

9. Bäckstrand, K.; Lövbrand, E. (Eds.) Research Handbook on Climate Governance; Edward Elgar Publishing: Cheltenham, UK, 2015.

10. Biermann, F. Earth System Governance; MIT Press: Cambridge, MA, USA, 2014.

11. Bulkeley, H.; Newell, P. Governing Climate Change; Routledge: Abingdon, UK, 2015.

12. Galaz, V. Global Environmental Governance, Technology and Politics; Edward Elgar Publishing: Cheltenham, UK, 2014.

13. Jordan, A.; Huitema, D.; Van Asselt, H.; Forster, J. Governing Climate Change: Polycentricity in Action? Cambridge University Press: Cambridge, UK, 2018.

14. Lieven, A. Climate Change and the Nation State; Penguin: London, UK, 2021.

15. Betsill, M.M.; Bulkeley, H. Cities and the Multilevel Governance of Global Climate Change. Glob. Gov. 2006, 12, 141-160. [CrossRef]

16. Bulkeley, H.; Betsill, M.M. Revisiting the urban politics of climate change. Environ. Politics 2013, 22, 136-154. [CrossRef]

17. Chatterton, P. Unlocking Sustainable Cities; Pluto Press: London, UK, 2018.

18. ICLEI. ICLEI in the Urban Era: Our Vision for a Sustainable Urban World; ICLEI: Bonn, Germany, 2021.

19. Lee, T. Global Cities and Climate Change; Routledge: New York, NY, USA, 2016.

20. Low, S.; Boettcher, M. Delaying Decarbonization: Climate Governmentalities and Sociotechnical Strategies from Copenhagen to Paris. Earth Syst. Gov. 2020, 5, 100073. [CrossRef]

21. Moloney, S.; Hartmut, H.; Granberg, M. (Eds.) Local Action on Climate Change: Opportunities and Constraints; Routledge: Abingdon, $\mathrm{UK}, 2018$.

22. Thorpe, D. “One Planet" Cities; Earthscan/Routledge: Abingdon, UK, 2019.

23. Vedeld, T.; Hofstad, H.; Solli, H.; Hanssen, G.S. Polycentric urban climate governance: Creating synergies between integrative and interactive governance in Oslo. Environ. Policy Gov. 2021, 31, 347-360. [CrossRef]

24. Howarth, C.; Lane, M.; Slevin, A. (Eds.) Addressing the Climate Crisis; Palgrave Macmillan: London, UK, 2022.

25. Parry, I.; Black, S.; Vernon, N. Still Not Getting Energy Prices Right: A Global and Country Update of Fossil Fuel Subsidies; IMF: Washington, DC, USA, 2021.

26. Stoddard, I.; Anderson, K.; Capstick, S.; Carton, W.; Depledge, J.; Facer, K.; Gough, C.; Hache, F.; Hoolohan, C.; Hultman, M.; et al. Three Decades of Climate Mitigation: Why Haven't We Bent the Global Emissions Curve? Annu. Rev. Environ. Resour. 2021, 46, 653-689. [CrossRef]

27. Ostrom, E. Polycentric systems for coping with collective action and global environmental change. Glob. Environ. Chang. 2010, 20, 550-557. [CrossRef]

28. Wittmayer, J.M.; Van Steenbergen, F.; Rok, A.; Roorda, C. Governing sustainability: A dialogue between Local Agenda 21 and transition management. Local Environ. 2015, 21, 939-955. [CrossRef]

29. Copus, C.; Roberts, M.; Wall, R. Local Government in England: Centralisation, Autonomy and Control; Palgrave Macmillan: London, UK, 2017.

30. Stanton, J. Democratic Sustainability in a New Era of Localism; Routledge: Abingdon, UK, 2014.

31. Harris, T.; Hodge, L.; Phillips, D. English Local Government Funding: Trends and Challenges in 2019 and Beyond; Institute of Fiscal Studies: London, UK, 2019.

32. Gray, M.; Barford, A. The depths of the cuts: The uneven geography of local government austerity. Camb. J. Reg. Econ. Soc. 2018, 11, 541-563. [CrossRef]

33. Fenwick, J. The problem of sub-national governance in England. Public Money Manag. 2014, 35, 7-14. [CrossRef]

34. Shutt, J.; Liddle, J. Are Combined Authorities in England strategic and fit for purpose? Local Econ. J. Local Econ. Policy Unit 2019, 34, 196-207. [CrossRef]

35. National Audit Office. Local Government and Net Zero in England, National Audit Office; HM Government: London, UK, 2021.

36. Ogden, K.; Phillips, D.; Sion, C. What's happened and what's next for councils? In The IFS Green Budget; Institute for Fiscal Studies: London, UK, 2021. 
37. Green Alliance. The Local Climate Challenge: A New Partnership Approach. 2020. Available online: https://green-alliance.org. uk/the_local_climate_challenge.php (accessed on 14 September 2021).

38. Howarth, C.; Barry, J.; Dyson, J.; Fankhauser, S.; Gouldson, A.; Lock, K.; Owen, A.; Robins, N. Trends in Local Climate Action in the UK: A Report by the Place-Based Climate Action Network (PCAN); PCAN: London, UK, 2021.

39. County Councils Network. Rising to the Climate Challenge: The Role of County Councils in Delivering Net Zero 2021. Available online: https: / / www.countycouncilsnetwork.org.uk/the-government-risks-undermining-its-net-zero-target-by-focusing-oncities-instead-of-englands-counties-report-warns / (accessed on 30 September 2021).

40. UK100. Net Zero Local Leadership Communique 2021. Available online: https://www.uk100.org/publications/net-zero-localleadership-communique-delivering-net-zero-uk (accessed on 15 September 2021).

41. Committee on Climate Change. Net Zero The UK's Contribution to Stopping Global Warming. 2019. Available online: https://www.theccc.org.uk/publication/net-zero-the-uks-contribution-to-stopping-global-warming/ (accessed on 17 July 2021).

42. Committee on Climate Change. Policies for the Sixth Carbon Budget and Net Zero. London, UK. 2020. Available online: https:/ / www.theccc.org.uk/wp-content/uploads/2020/12/Policies-for-the-Sixth-Carbon-Budget-and-Net-Zero.pdf (accessed on 22 August 2021).

43. Committee on Climate Change. Joint Recommendations: 2021 Report to Parliament; Climate Change Committee: London, UK, 2021. Available online: https:/ / www.theccc.org.uk/wp-content/uploads/2021/06/CCC-Joint-Recommendations-2021-Report-toParliament.pdf (accessed on 17 August 2021).

44. House of Commons Public Accounts Committee. Achieving Net Zero 2021. London, UK. Available online: https://publications. parliament.uk/pa/cm5801/cmselect/cmpubacc/935/93502.htm (accessed on 20 September 2021).

45. Sasse, T.; Rutter, J.; Shepheard, M.; Norris, E. Net Zero: How Government Can Meet Its Climate Change Target; Institute for Government: London, UK, 2020.

46. BEIS. The Ten Point Plan for a Green Industrial Revolution. London, UK. 2020. Available online: https://www.gov.uk/ government/publications/the-ten-point-plan-for-a-green-industrial-revolution (accessed on 20 September 2021).

47. Arroyo, V. From Paris to Pittsburgh: US State and Local Leadership in an Era of Trump. Geo. Envtl. L. Rev. 2018, 31, 433.

48. Patterson, J.J. Remaking Political Institutions: Climate Change and Beyond. Elements in Earth System Governance; Cambridge University Press: Cambridge, UK, 2020.

49. Bäckstrand, K.; Kuyper, J.W. The democratic legitimacy of orchestration: The UNFCCC, non-state actors, and transnational climate governance. Environ. Politics 2017, 26, 764-788. [CrossRef]

50. ICLEI. Local Sustainability: Taking Stock and Moving Forward; ICLEI: Bonn, Germany, 2012.

51. Barber, B. If Mayors Ruled The World; Yale University Press: New Haven, CT, USA, 2013.

52. Ostrom, E. Governing the Commons: The Evolution of Institutions for Collective Action; Cambridge University Press: Cambridge, UK, 1990.

53. Ostrom, E. A Polycentric Approach for Coping with Climate Change. Ann. Econ. Financ. 2014, 15, 97-134.

54. Yin, R.K. Case Study Research: Design and Methods, 1st ed.; SAGE Publications Ltd.: London, UK, 2009.

55. Legatum Institute. The United Kingdom Prosperity Index. London, UK. 2021. Available online: https://li.com/reports/ukprosperity-index-2021/ (accessed on 17 August 2021).

56. ONS. 2011 Census: Usual Resident Population and Population Density, Local Authorities in the United Kingdom. Available online: https:/ / www.ons.gov.uk/file?uri=/peoplepopulationandcommunity/populationandmigration/populationestimates / datasets /2011censuspopulationandhouseholdestimatesfortheunitedkingdom/r01ukrttable2v2_tcm77-292364.xls (accessed on 23 June 2021).

57. Russell, E.; Christie, I.; Murphy, R. Surrey Carbon Baseline Report; Surrey Climate Commission: Guildford, UK, 2021. Available online: https: / / www.surreyclimate.org.uk/sites/default/files/SvCComm\%20Baseline\%20Report\%20-\%20Final\%20Version\% 2023.4.21.pdf (accessed on 15 August 2021).

58. SCC Agenda and Minutes Council-Tuesday, 9 July 201910.00 Am. Available online: https://mycouncil.surreycc.gov.uk/ ieListDocuments.aspx?CId=121\&MId=6659\&Ver=4 (accessed on 17 June 2021).

59. ONS. Estimates of the Population for the UK, England and Wales, Scotland and Northern Ireland. 2021. Available online: https:/ / www.ons.gov.uk/peoplepopulationandcommuni-ty/populationandmigration/populationestima-tes/datasets / populationestimatesforukenglandandwalesscotlandandnorthernire-land (accessed on 13 July 2021).

60. ONS. Parish Population Estimates for Mid-2001 to Mid-2019 Based on Best-Fitting of Output Areas to Parishes. 2021. Available online: https:/ / www.ons.gov.uk/peoplepopulationandcommunity/populationandmigration/populationestimates/adhocs/ 12324parishpopulationestimatesformid2001 tomid2019basedonbestfittingofoutputareastoparishes (accessed on 13 July 2021).

61. DCLG. Transparency Code for Smaller Authorities 2014. Available online: https://www.gov.uk/government/publications/ transparency-code-for-smaller-authorities (accessed on 23 August 2021).

62. HM Government. The Openness of Local Government Bodies Regulations 2014. UK. 2014. Available online: https://www. legislation.gov.uk/uksi/2014/2095/contents/made (accessed on 24 August 2021).

63. Childs, M. 20 Actions Parish and Town Councils Can Take on the Climate and Nature Emergency. Available online: https: / / policy.friendsoftheearth.uk/reports/20-actions-parish-and-town-councils-can-take-climate-and-nature-emergency (accessed on 14 July 2021). 
64. University of Exeter. Centre for Sustainable Energy. Online Tool Measures Community Carbon Footprint. Available online: https://www.exeter.ac.uk/sustainability/newsandevents/archive/title_850346_en.html (accessed on 18 March 2021).

65. The UK Government Climate Change Act 2008. UK. 2008. Available online: https://www.legislation.gov.uk/ukpga/2008/27/ contents (accessed on 19 September 2021).

66. Abbott, K.W.; Genschel, P.; Snidal, D.; Zangl, B. International Organizations as Orchestrators; Cambridge University Press: Cambridge, UK, 2015.

67. BEIS. UK Becomes First Major Economy to Pass Net Zero Emissions Law. Available online: https://www.gov.uk/government/ news / uk-becomes-first-major-economy-to-pass-net-zero-emissions-law (accessed on 1 August 2021).

68. Pahl-Wostl, C.; Knieper, C. The Capacity of Water Governance to Deal with the Climate Change Adaptation Chal-lenge: Using Fuzzy Set Qualitative Comparative Analysis to Distinguish between Polycentric, Fragmented and Centralized Regimes. Glob. Environ. Chang. 2014, 29, 139-154. [CrossRef]

69. Abbott, K.W. Orchestration. Strategic Ordering in Polycentric Governance. In Governing Climate Change: Polycentricity in Action? Jordan, A., Huitema, D., Van Asselt, H., Forster, J., Eds.; Cambridge University Press: Cambridge, UK, 2018. 